\title{
EFEKTIVITAS PENILAIAN PEMBELAJARAN MATEMATIKA SELAMA MASA PANDEMI COVID-19 SDK NDONA 2 KECAMATAN NDONA KABUPATEN ENDE
}

\author{
Maria Ana ${ }^{1}$, Theodosia Ndole ${ }^{2}$ \\ ${ }^{1}$ Kepala Sekolah SDK Ndona 2, Jl. Trans Wolowona- Ndona \\ ${ }^{2}$ Guru SDK Ndona 2, Jl. Trans Wolowona-Ndona \\ Email: 05mariaana@gmail.com
}

\begin{abstract}
This study aims to determine the effectiveness of the assessment of mathematics learning during the COVID-19 pandemic at SDK Ndona 2, Ndona District, Ende Regency. This type of research is qualitative research with data collection techniques in this study carried out by means of observation, interviews, and documentation. After the data was collected, the data were analyzed qualitatively. The results of this study indicate that the effectiveness of assessing mathematics learning during the COVID-19 pandemic only focuses on the cognitive assessment of students, therefore teachers have other techniques in carrying out mathematics learning assessments so that they can provide a real picture of students' abilities. The conclusion from the results of this study is that during this pandemic the assessment of mathematics learning has been effective. This is because the assignment given by the teacher is not done by students but is served by someone else (parents, siblings).
\end{abstract}

Keywords: effectiveness; assessment of mathematics learning; during; the pandemi COVID-19.

\begin{abstract}
Abstrak
Penelitian ini bertujuan untuk mengetahui efektivitas penilaian pembelajaran matematika selama masa pandemi COVID-19 di SDK Ndona 2 Kecamatan Ndona Kabupaten Ende. Jenis penelitian yang digunakan adalah penelitian kualitatif dengan teknik pengumpulan data dalam penelitian ini dilakukan dengan cara observasi, wawancara, dan dokumentasi. Setelah data dikumpulkan, data dianalisis secara kualitatif. Hasil penelitian ini menunjukkan bahwa efektivitas penilaian pembelajaran matematika pada masa pandemi COVID-19 ini hanya berfokus kepada penilaian kognitif peserta didik, maka dari itu guru memiliki teknik lain dalam melaksanakan penilaian pembelajaran matematika supaya bisa memberikan gambaran nyata dari kemampuan peserta didik. Kesimpulan dari hasil penelitian ini adalah di masa pandemi ini penilaian pembelajaran matematika berjalan efektif. Hal ini disebabkan karena tugas yang diberikan oleh guru, tidak serta merta dikerjakan oleh siswa tetapi diabntu oleh orang lain (Orang Tua, Kakak ).
\end{abstract}

Kata kunci: Efektivitas; Penilaian Pembelajaran Matematika; Masa Pandemi COVID-19.

\section{PENDAHULUAN}

Pembelajaran matematika adalah suatu proses pemberian pengalaman belajar matematika kepada peserta didik yang melewati beberapa rangkaian kegiatan yang telah disusun secara terencana sehingga peserta didik mendapatkan pengetahuan tentang matematika yang dipelajarinya (Amir, 2014). Apapun kondisi saat ini, pendidikan dan pembelajaran akan tetap dilakukan sebagai upaya untuk membantu siswa dalam meningkatkan pemahaman dan kemampuan yang dimiliki siswa, dalam hal ini yang dimaksud adalah potensi dalam kemampuan matematika. Pemahaman 
berpikir matematika didapatkan ketika siswa melaksanakan pembelajaran matematika dengan baik, ini merupakan tujuan penting pendidikan agar siswa dapat menyelesaikan masalah dengan berbagai bentuk penyelesaian dan strategi (Stacey, 2006; Jacobs, Lamb \& Philipp, 2010; Nugraha, Suryadi \& Syam, 2015). Berbicara tentang pembelajaran matematika, berarti tidak akan terlepas pula dari penilaian matematika karena keduanya adalah dua sisi yang saling beriringan.

Pandemi COVID-19 memberikan dampak kepada banyak pihak, salah satunya adalah pada bidang pendidikan. Kegiatan pembelajaran menjadi terganggu dengan adanya wabah ini (Zhou \& Chen, 2020; Tian, et. al, 2020). Kegiatan pembelajaran yang awalnya dilakukan secara tatap muka kemudian dilakukan secara daring (dalam jaringan), luring (luar jaringan). Pembelajaran daring merupakan suatu metode belajar yang menggunakan model interaktif berbasis Internet dan Learning Manajemen System (LMS), seperti menggunakan zoom, Google meet, Google Drive dan sebagainya. Kegiatan daring diantaranya Webinar, kelas online, seluruh kegiatan yang dilakukan menggunakan jaringan internet dan komputer (Hasibuan, Simarmata, \& Sudirman, 2019). Pembelajaran daring sulit dilakukan bagi daerah-daerah pedalaman yang susah jaringan (Sulha, 2020). Apabila jaringan tidak cukup, dapat mengakibatkan siswa ketinggalan materi karena tidak mengikuti kegiatan pembelajaran tepat waktu (Yensy, 2020). Selain karena susah jaringan, hal lain yang menyebabkan sulit untuk dilakukan pembelajaran secara daring adalah karena ketersediaan gadget dari para orang tua. Gadget menjadi salah satu faktor pendukung dalam pembelajaran daring karena jika tanpa adanya gadget pembelajaran daring tidak akan terlaksana dengan baik (Putria, Maulana, \& Uswatun, 2020). Dalam penelitian Harahap, Dimyati, \& Purwanta (2021) penerapan pembelajaran dalam jaringan memiliki problematika dalam pelaksanaanya antara lain sarana dan prasarana, kurangnya pemahaman, ketidaksiapan guru maupun orang tua serta penilaian.

Pembelajaran luar jaringan (luring) merupakan pembelajaran yang bisa dilakukan di daerah yang sulit mendapakan jaringan. Pembelajaran luring yang dapat digunakan yaitu pembelajaran home visit dan shift (bergantian). Home visit merupakan salah satu metode pembelajaran dimana guru mengunjungi siswa dirumah masing-masing. Kegiatan pembelajaran home visit ini biasa disebut dengan belajar dari rumah (BDR) dimana guru akan mendatangi rumah-rumah siswa secara bergantian untuk melakukan pembelajaran. Guru akan hadir dalam door to door pada siswa (Sulha, 2020). Berdasarkan penelitian yang dilakukan oleh Harahap, Dimyati, \& Purwanta (2021) pembelajaran home visit (BDR) digunakan pada daerah desa/pelosok yang sangat kesulitan saat menggunakan pembelajaran daring. Sedangkan shift (masuk secara bergantian) merupakan kegiatan yang dilakukan guna mengikuti protokol kesehatan demi menghindari kegiatan yang mengundang keramaian (Harahap, Dimyati, \& Purwanta, 2021). Shift merupakan pembelajaran tatap muka yang dilakukan secara bergantian di sekolah, dan hanya diterapkan bagi sekolah yang berada pada zona hijau atau kuning (Sulha, 2020) 
Pada masa pandemi ini semua proses pembelajaran di sekolah-sekolah mengalami perubahan yang sangat signifikan. Lebih banyak proses pembelajaran dilakukan dari rumah atau guru-guru dari rumah ke rumah. Pendidikan merupakan suatu proses yang berlangsung secara berkesinambungan guna meningkatkan kecerdasan dan keterampilan melalui proses belajar khususnya pada masa pandemi COVID-19 saat ini. Pemerintah menginstruksikan kepada tenaga pendidik dan kependidikan agar pada masa pandemi ini bisa menerapkan pembelajaran dari rumah. Hal ini terjadi karena COVID-19 melanda seluruh negeri di belahan dunia termasuk Indonesia. COVID-19 merupakan penyakit menular, yang dapat menyebar, baik secara langsung maupun tidak langsung, dari satu orang ke orang lain. Salah satu cara untuk memutus mata rantai penyebaran COVID-19 adalah dengan melakukan pembatasan interaksi masyarakat yang diterapkan dengan istilah jaga jarak (Lee, 2020., Mustakim, 2020, Sun, Tang, \& Zuo, 2020., Murfi, dkk, 2020). Kebijakan jaga jarak tersebut dapat menghambat laju pertumbuhan dalam berbagai bidang kehidupan, baik bidang ekonomi, sosial, kesehatan maupun dalam bidang pendidikan.

Komponen penting dalam pembelajaran yang harus dilakukan oleh guru adalah proses penilaian pembelajaran. Proses penilaian diartikan sebagai suatu peran utama dalam mengetahui bagaimana guru mengajarkan sesuatu dan apa yang didapatkan siswa setelah mempelajari sesuatu tersebut, yang memungkinkan pemahaman siswa mengenai informasi, kelemahan, serta kekuatan matematika yang ada pada siswa (Adams, 1998; NCTM, 1989). Hal ini tentu akan membantu guru untuk meningkatkan kualitas belajar siswa. Pandangan yang lebih luas tentang penilaian juga dijelaskan oleh National Council of Teacher of Mathematics (NCTM, 1989) yang mensyaratkan beberapa aspek yang tepat mengenai kemahiran dalam pembelajaran matematika siswa. Beberapa aspek tersebut di antaranya yaitu konsep dan prosedur, proses dan praktik matematika, dan yang terakhir adalah disposisi terhadap matematika.

Merujuk pada penelitian sebelumnya sudah banyak yang mengkaji tentang penilaian matematika, seperti diantaranya penilaian matematika berbasis kognisi, penilaian matematika dengan self evaluation (Ross, et.al, 2002), maupun penelitian mengenai bagaimana guru menggunakan berbagai faktor untuk menilai siswanya, baik melalui jenis penilaian yang digunakan, penilaian kognitif, maupun nilai yang diberikan (McMillan, Myran, \& Workman, 2002). Diantara beberapa penelitian yang sudah ada, belum nampak penelitian yang mengkaji mengenai penilaian pembelajaran matematika selama masa pandemic covid -19 , dengan alasan bahwa virus ini masih terus menghantui kita sehingga proses dan aktivitas semuanya terhambat.

Sebagai sesuatu yang sangat penting, penilaian wajib dilaksanakan oleh guru dalam suatu pembelajaran karena melalui penilaian guru bisa mengetahui kekurangan dan kelebihan saat melaksanakan pembelajaran. Berdasarkan pendapat tersebut, penilaian merupakan proses kegiatan yang dilakukan untuk mengumpulkan suatu informasi tentang proses kerja sesuatu atau seseorang, 
yang mana selanjutnya informasi tersebut akan digunakan sebagai upaya dalam menentukan alternatif yang tepat dalam mengambil sebuah keputusan (Arikunto \& Jabar, 2004). Dalam melakukan penilaian pembelajaran matematika maka guru harus memiliki strategi yang tepat dalam melaksanakannya supaya bisa memberikan gambaran sebenarnya dari siswa. Selain itu guru dapat mengetahui efektif atau tidaknya suatu penilaian pembelajaran, maka guru harus memberikan nilai dengan cara apapun itu.

Penilaian menurut Permendikbud nomor 23 tahun 2016 tentang penilaian hasil belajar memuat tiga aspek yaitu sikap, pengetahuan, dan keterampilan. Ketiga aspek penilaian inilah yang akan dijadikan sebagia laporan akhir penilaian guru terhadap siswa, akan tetapi penilaian pembelajaran matematika yang dapat dilakukan guru terhadap peserta didik saat belajar dari rumah (BDR) pada masa pandemi COVID-19 adalah penilaian yang dilaksanakan secara langsung dengan memberikan penugasan kepada peserta didik, dan dari nilai tugas tersebut akan dijadikan sebagai nilai akhir.

Dalam proses belajar dari rumah semestinya peserta didik bisa belajar secara mandiri, dan juga peserta didik membutuhkan pendamping dari guru serta orang tua dalam meningkatakan budaya literasi serta mengembangkan pola pikir anak. Problematika saat ini adalah masih banyak peserta didik yang menganggap matematika pelajaran yang sulit. Sebagaimana pendapat Auliya (2016), matematika dianggap sebagai pelajaran yang sulit karena karakteristik matematika yang bersifat abstrak, logis, sistematis, dan penuh dengan lambang serta rumus yang membingungkan. Kesulitan yang ada dalam mata pelajaran matematika menuntut kreativitas guru mata pelajaran matematika untuk mengembangkan pembelajarannya, baik dalam hal model maupun metode yang digunakan.

Pembelajaran matematika pada dasarnya memiliki karakteristik yang nyata, serta konsep dan prinsipnya yang berjenjang. Hal ini menyebabkan banyak siswa yang merasa kesulitan dalam menerima pembelajaran matematika yang diberikan oleh guru. Pembelajaran matematika bagi siswa sekolah dasar kelas I, II dan III diintegrasikan ke dalam tema-tema yang dipelajari. Namun untuk kelas tinggi yaitu kelas IV, V dan VI materi matematika dipisahkan dari buku tematik terpadu.

Pembelajaran dilaksanakan di rumah yang dilaksanakan secara BDR tanpa bertatap langsung dengan siswa untuk memberikan pengalaman belajar yang lebih bermakna bagi siswa. Utamanya dalam pembelajaran matematika untuk siswa kelas tinggi di sekolah dasar penyusunan materi serta penggunaan alat peraga atau media pembelajaran dalam proses pembelajaran yang dialami selama masa pandemi ini yang dilakukan oleh guru dengan siswa harus disesuaikan dengan tingkat perkembangan intelektual siswa, dibimbing secara bertahap untuk menguasai konsep dalam matematika agar dapat meningkatkan keefektifan dan memaksimalkan pembelajaran matematika. Selama proses pembelajaran yang dilaksanakan BDR harus dijadikan tantangan bagi pendidik untuk mentransformasi pendidikan yang lebih maju lagi. Khususnya dalam pembelajaran matematika yang 
dirasakan oleh sebagian besar peserta didik akan sulit dipelajari jika tidak langsung bertatap muka dengan guru.

Sesuai dengan hasil observasi peneliti di SDK Ndona 2, ditemukan fakta-fakta bahwa semua guru di SDK Ndona 2 melakukan proses pembelajaran secara BDR dan semi online (WhatsApp). Begitupun dengan tugas-tugas yang diberikan guru kepada siswa dilakaukan secara semi online artinya ada yang dikirim melalaui WhatsApp dan juga orang tua yang mengambil tugas di sekolah. Penilaian sebagai hasil dari tugas-tugas yang diberikan guru kepada peserta didik menunjukkan hal yang berbeda dengan perolehan nilai jika tugas-tugas tersebut diberikan secara tatap muka. Rata-rata perolehan nilai siswa pada masa pandemi COVID-19 meningkat secara drastis hal ini dibenarkan oleh situasi di mana penyelesaian tugas-tugas di rumah tidak sepenuhnya dilakukan siswa melainkan bantuan dari orang tua, hal ini menandakan bahwa perolehan nilai siswa tersebut bukan merupakan gambaran nyata prestasi belajar siswa itu sendiri. Untuk itu dalam penilaian dibutuhkan strategi guru dalam melaksanakan penilaian pembelajaran sehingga gambaran nilai siswa menjadi lebih objektif.

Berdasarkan permasalahan yang telah diuraikan maka penelitian ini bertujuan untuk mengetahu "Efektivitas Penilaian pembelajaran matematika selama masa pandemi COVID-19 di SDK Ndona 2 Kecamatan Ndona Kabupaten Ende".

\section{METODE}

Jenis penelitian ini adalah penelitian kualitatif dengan pendekatan fenomenologi. Karena akan mendeskripsikan keefektivan proses penilaian pembelajaran matematika pada masa pandemi COVID-19 di sekolah dasar lebih khusus di SDK Ndona 2. Pendekatan kualitatif yaitu penelitian yang dilakukan pada obyek alamiah dengan mendeskripsikan keadaan yang sebenarnya dan menyajikannya dalam bentuk kata-kata (Sugiyono, 2008). Obyek alamiah adalah obyek berkembang dilingkungan yang terjadi apa adanya, tidak dimanipulasi atau direkayasa oleh peneliti dan kehadiran peneliti tidak begitu mempengaruhi dinamika pada obyek tersebut Sugiyono (Sugiyono, 2008,). Penelitian ini menggunakan 3 (tiga) teknik pengumpulan data yaitu observasi, wawancara dan dokumentasi. Teknis analisis data yang dilakukan yaitu, reduksi data, penyajian data setelah pengumpulan data, dan tahap penarikan kesimpulan dan verifikasi.

\section{HASIL DAN PEMBAHASAN}

\section{Kefektifan penilain pemebelajaran matematika di masa Pandemi Covid - 19}

Berdasarkan hasil observasi yang dilakukan oleh peneliti, bahawa proses penilaian pembelajaran matematika di SDK Ndona 2 pada masa pandemik ini hanya menilai kognitifnya saja. Hal ini dibuktikan dengan pemberian tugas-tugas oleh guru kemudian dikerjakan oleh siswa di rumah. Sehingga proses penilaianya adalah guru melihat tingkat kerajinan siswa mengumpulkan tugas yang diberikan oleh guru dan juga penilaian hasil jawaban benar dan salahnya dari tugas yang 
diberikan. Tugas yang diberikan oleh guru dilakukan setiap minggu, atau satu minggu satu kali tugas. Proses ini bukan hanya matapelajaran matematika saja, tetapi hampir semua matapelajaran di SDK Ndona 2.

Pemberian nilai yang dilakukan oleh guru adalah dengan penilaian portofolio, artinya guru mengumpulkan tugas-tugas yang diberikan kepada siswa. Setelah itu guru menganalisis kumpulankumpulan tugas dari siswa tersebut dihargai sebagai hasil kerja dari proses pembelajaran yang dilakukan oleh siswa di rumah. Tugas-tugas yang diberikan oleh guru, siswa wajib mengerjakannya di dalam buku latihan siswa dan kemudian diantar ke sekolah oleh orang tua. Penilaian pembelajaran matematika juga dilakukan secara langsung oleh guru dengan cara membagi siswa menjadi beberapa kelompok yang mana setiap kelompok maksimal tujuh orang dalam satu kelas setiap sesinya. Kegiatan BDR tetap mentaati protokol kesehatan guna mencegah penularan virus COVID-19.

Dalam satu hari terdapat dua kelompok belajar dengan waktu pelaksanan dimulai dari jam 08. 00 sampai 09. 30, kemudian dilanjutkan dengan pertemuan berikutnya dimulai dari jam 10.00 sampai dengan 11. 30. Selama proses pembelajaran pertama guru memberikan batasan-batasan materi yang dipelajari di rumah yang nantinya siswa memperoleh sumbernya dari internet atau sumber lainya sesuai dengan situasi saat ini yang siswa alami di lingkungan mereka berada. Setelah beberapa hari guru berkunjung ke rumah siswa disaat itu juga langsung memeriksa hasil kerja siswa, yang pada akhirnya dapat memberikan penilaian. Jika ada siswa yang belum dapat menyelesaikan atau belum paham dengan tugas tersebut guru langsung memberikan kesimpulan akhir.

Hal ini diperkuat lagi dengan hasil wawancara dengan salah seorang guru SDK Ndona 2 Kecamatan Ndona Kabupaten Ende menjelaskan bahwa selama Covid mereka hanya memfokuskan penilaian pada penilaian kognitif atau pengetahuan siswa saja karena dengan kondisi sekarang ini yang mengharuskan semua sekolah untuk melakukan belajar secara daring dan tidak ada pembelajaran tatap muka, maka dari itu dalam melaksanakan penilaian pembelajaran matematika mereka selalu mengoreksi tugas yang telah dikumpulkan orang tua setiap hari sabtu, dari tugas itu nanti akan ada penilaiannya yang diambil berupa kerajinan siswa dalam mengumpulkan tugas, kerapian dalam mengerjakan soal, dan benar salahnya dalam mengerjakan soal matematika yang diberikan.

Berdasarkan hasil wawancara di atas disimpulkan bahwa penilaian pembelajrana matematika di masa pandemic COVID-19 ini hanya fokus pada penilaian kognitif saja. Sementara afektif dan psikomotorik tidak bisa dilakukan. Dengan alasan guru hanya bisa menilai hasil portofolio dari masing-masing tugas siswa. Selain itu guru juga mengkoreksi jawaban dari setiap hasil pekerjaan siswanya. Menurut guru-guru di SDK Ndona 2 penilaian afektif dan psikomotor hanya dapat dilakukan dengan tatap muka, sementara pembelajaran BDR guru tidak mampu melakukan observasi tersebut. Melakukan pembelajaran matematika secara daring dirasa lebih sulit, sebab menurut guru, 
matematika memerlukan penggunaan rumus-rumus yang perlu diajarkan secara langsung ke siswa. Dalam melaksanakan penilaian secara daring, guru tidak bisa memantau keterampilan matematika masing-masing siswa secara indivdu. Guru dan siswa tidak pernah menggunakan aplikasi yang berbasis video, sehingga guru tidak mampu mengamati secara langsung bagaimana kemahiran dan keterampilan siswa dalam mengerjakan tugas-tugas matematika. Sehingga dalam menilai dan merekap hasil belajar matematika siswa, guru seringkali mendapati keraguan akan hasil yang diperoleh siswa. Jawaban yang diberikan oleh siswa lebih cenderung sempurna. Walaupun lebih banyak siswa yang menyukai proses pembelajaran secara tatap muka, tetapi situasi yang tidak memungkinkan untuk melakukan kegiatan belajar mengajar secara tatap muka, dengan alasan pandemi COVID-19 masih merajalela.

Pembelajaran merupakan proses interaksi siswa dengan pendidik dan sumber belajar pada suatu lingkungan belajar. Pembelajaran dapat dilakukan dimana saja salah satunya di sekolah. Namun kondisi saat ini sistem pembelajaran di Sekolah tidak dapat dilaksanakanseperti biasanyamelalui tatap muka, tetapi pembelajaran dilaksanakan secara BDR karena adanya Pandemi COVID-19. Proses pembelajaran matematika yaitu suatu kegiatan belajar ilmu pengetahuan menggunakan nalar dan memiliki rencana terstruktur dengan melibatkan pikiran serta aktifitas dalam mengembangkan kemampuan pemecahan masalah dan menyampaikan suatu informasi atau gagasan.

Berdasarkan hasil wawancara dengan seorang guru kelas di SDK Ndona 2 pada tanggal 21 April 2020 tentang proses pembelajaran matematika selama masa pandemi COVID-19 diketahui bahwa proses pembelajaran matematika selama masa Pandemi COVID-19 di SDK Ndona 2 tetap dijalankan. Pembelajaran matematika dilaksanakan di luar jaringan atau BDR yang dilaksanakan di rumah siswa, dengan pembagian kelompok belajar. Dalam satu hari terdapat dua kelompok belajar dengan waktu pelaksanan dimulai dari jam 08.00 sampai 09.30, kemudian dilanjutkan dengan pertemuan berikutnya dimulai dari jam 10.00 sampai dengan 11.30. Selama proses pembelajaran pertama guru memberikan batasan-batasan materi yang dipelajari di rumah yang nantinya siswa memperoleh sumbernya dari internet atau sumber lainya sesuai dengan situasi saat ini yang siswa alami di lingkungan mereka berada. Setelah beberapa hari guru langsung berkunjung ke rumah peserta didik disaat itu juga guru langsung periksa hasil kerja siswa, yang pada akhirnya dapat memberikan penilaian.

Dari beberapa pernyataan di atas peneliti dapat menyimpulkan bahwa proses pembelajaran matematika selama masa pandemi COVID-19 tetap dijalankan secara maksimal, dan proses penilaiannya juga efektif walaupun afektif dan psikomotorik tidak berjalan normal. Dengan penilaian portofolio yaitu dengan mengumpulkan tugas-tugas dari hasil kerja siswa. Sehingga hal inilah yang menjadi tolak ukur kefektifan penilain pembelajaran matematika di masa pandemic Covid -19 saat ini. 


\section{KESIMPULAN}

Berdasarkan hasil penelitian tersebut di atas tentang Efektifitas penilaian pembelajaran matematika pada masa pandemi COVID-19 di SDK Ndona 2 Kecamatan Ndona Kabupaten Ende dapat simpulkan bahwa pelaksanaan penilaian pembelajaran matematika pada masa pandemi COVID-19 saat ini berlangsung efektif walaupun proses penilaiannya hanya kognitif saja, namun guru dapat mengetahui kemampuan dari siswa yang sebenarnya. Selain itu penilaian pembelajaran matematika pada masa pandemi COVID-19 ini juga dilakukan dengan penilaian portofolio dan penilaian langsung yaitu berdasarkan dari tugas-tugas yang diberikan kepada siswa dan penilaian tatap muka langsung malalui pembagian kelompok belajar di rumah siswa.

\section{SARAN}

Berdasarkan kesimpulan di atas, maka peneliti dapat mengemukakan saran-saran yang kiranya dapat diperhatikan oleh guru dalam penilaian pembelajaran matematika selama masa pandemi COVID-19 yang dijalankan di luar jaringan atau secara BDR di tengah pandemi COVID-19 ini. Adapun saran-saran yang dimaksudkan adalah sebagi berikut:

\section{Bagi Guru}

Agar penilaian pembelajaran matematika selama masa Pandemi COVID-19 di SDK Ndona 2 dapat berjalan dengan baik, sebaiknya guru dapat mempersiapkan berbagai strategi penilaian pembelajaran. Agar siswa tidak hanya dinilai kognitifnya saja tetapi afektif dan psikomotorik juga perlu dinilai.

2. Bagi Orang Tua

Orang tua peserta didik harus turut berpartisipasi aktif untuk membangun motivasi belajar anaknya dan terus mendampingi proses belajar selama masa pandemi COVID-19 karena siswa tidak memperoleh materi sepenuhnya dan sebagi nilai siswa hanya diperoleh dari tugas saja.

3. Bagi siswa

Siswa diharapkan dapat mengetahui hasil penilaian yang diperoleh di tengah pandemi COVID19 sehingga siswa dapat membedakan penilaian yang diperoleh sebelum masa pandemi COVID-19 dan selama masa pandemi COVID-19. Dengan adanya penilaian siswa dapat mengetahui sejauh mana telah berhasil mengikuti pelajaran yang telah diberikan oleh guru di tengah pandemi COVID-19.

\section{DAFTAR PUSTAKA}

Adams, T. L. (1998). Alternative Assessment in Elementary School Mathematics. Journal Childhood Education,74 (4), 220-224.

Amir, A. (2014). Pembelajaran Matematika SD dengan Menggunakan Media Manipulatif. Forum Paedagogik, 6(01). 
Arikunto, S., Jabar, C. S. A. (2004). Evaluasi Program Pendidikan Pedoman Teoritis Praktis Bagi Praktisi Pendidikan. Jakarta: Bumi Aksara.

Auliya, R. N. (2016). Kecemasan Matematika dan Pemahaman Matematis. Formatif. Jurnal Ilmiah Pendidikan MIPA, 6 (1), 12-22. https://doi. org/10. 30998/formatif. V6i1. 748.

Harahap, S. A., Dimyati., Purwanta, E. (2021). Problematika Pembelajaran Daring dan Luring Anak Usia Dini bagi Guru dan Orang tua di Masa Pandemi Covid 19. Jurnal Obsesi: Jurnal Pendidikan Anak Usia Dini, 5(2), 1825-1836.

Hasibuan, M. S., Simarmarta, J., Sudirman, A. (2019). E-learning: Implementasi, Strategi dan Inovasinya. Medan: Yayasan Kita Menulis.

Jacobs, V. R., Lamb, L. L. C., Philipp, R. A. (2010). Professional Noticing of Children's Mathematical Thinking. San Diego. Journal for Research in Mathematics Education, 41(2), 169-202.

Lee, A. (2020). Wuhan Novel Corona Virus (COVID-19): Why Global Control is Chalenging? Public Health, January, 19-21. Https: //doi.org/https://doi.org/10.1016/j.puh e.2020.02.001.

McMillan, J. H., Myran, S., Workman, D. (2002). ElementaryTeachers' Classroom Assessment and Grading Practices. The Journal Educational Research., 95(4), 203-213.

Murfi, A, dkk. (2020). Kepemimpinan Sekolah dalam Situasi Krisis Covid-19 di Indonesia. Manageria: Jurnal Manajemen Pendidikan Islam, 5(1).

Mustakim. (2020). Efektivitas Pembelajaran Daring Menggunakan Media Online selama Pandemi Covid-19 pada Mata Pelajaran Matematika. Al asma: Journal of Islamic Education, 2(1), 1-11.

NCTM. (1989). Curriculum and Evaluation Standards for School Mathematics. Reston, VA: NCTM.

Nugraha, A. M., Suryadi, K., Syam, S. (2015). Penggunaan Media Sosial Path Sebagai Sarana Pengakuan Sosial. Jurnal Sosietas, 5(2).

Permendikbud. (2016). Peraturan Menteri Pendidikan dan Kebudayaan Nomor 24 Tahun 2016 Tentang Kompetensi Inti dan Kompetensi Dasar Pelajaran Pada Kurikulum 2013 Pada Pendidikan Dasar dan Pendidikan Menengah.

Putria, H., Maulana, L., Uswatun, D. (2020). Analisis Proses Pembelajaran dalam Jaringan (DARING) Masa Pandemi COVID-19 pada Guru Sekolah Dasar. Jurnal Basicedu: Research \& Learning in Elemantary Education, 4(4), 861-872.

Ross, A., et. al. (2002). Student Self Evaluation in Grade 5-6 Mathematics Effects on ProblemSolving Achievement. Journal Educational Assessment.,8 (1) 43-59.

Stacey, Kaye. (2006). What is Mathematical Thinking and Why is it Important?.See discussions, stats, and author profiles for this publication at: https://www.researchgate.net/ publication/254408829. All content following this page was uploaded by Kaye Stacey on 13 June 2014.

Sugiyono. (2008). Metode Penelitian Kuantitatif Kualitatif dan R\&D. Bandung: Alfabeta. 
Sulha. (2020). Penerapan Montessori dalam Pembelajaran Matematika Melalui Luring Sebagai Alternatif Masa Pandemi. Jurnal Pendidikan dan Riset Matematika, 3(1), 22-30.

Sun, L., Tang, Y., Zuo, W. (2020). Coronavirus Pushes Education Online. Nature Materials, 20200205. https://doi.org/10.1038/s41563-020-0678-8.

Tian, S, et. al. (2020). Characteristics of COVID-19 Infection in Beijing. Journal of Infection, 80(4), 401-406. https://doi.org/10.1016/j.jinf.2020.02.018.

Yensy, N, A. (2020). Efektifitas Pembelajaran Statistika Matematika melalui Media Whatsapp Group Ditinjau dari Hasil Belajar Mahasiswa (Masa Pandemik Covid 19). Jurnal Pendidikan Matematika Raflesia, 5(02), 65-74.

Zhou, G., Chen, Z. (2020). Back to The Spring of Wuhan: Facts and Hope of COVID-19 Outbreak. Frontiers of Medicine, 1-4. https://doi.org/10.1007/s11684-020-0758-9. 